\title{
SEASONAL VARIATION IN OVARIAN RESPONSIVENESS OF THE CYCLING HAMSTER TO PMSG
}

\author{
PAMELA J. MOORE AND G. S. GREENWALD \\ Departments of Obstetrics and Gynecology and Anatomy, \\ University of Kansas Medical Center, \\ Kansas City, Kansas 66103, U.S.A.
}

(Received 30th Fuly 1973)

Several studies from this laboratory have used PMSG to induce superovulation in the cycling hamster (for references see Greenwald, 1973). The same dose of PMSG given at different times of the year resulted in different ovulation frequencies. This raised the question of whether there is a seasonal variation in ovarian responsiveness to exogenous gonadotrophins.

Aliquots of 5, 15 or 30 i.u. PMSG (concentration/0.1 ml), sufficient to last for 1 year, were prepared and frozen at the beginning of the experiment. Individual vials were then unfrozen and used only once. For 1 year, beginning in May 1972, on the 14th or 15th of each month, three groups of adult golden hamsters (five per group) were injected subcutaneously with 5, 15 or 30 i.u. of PMSG on the morning of Day 1 (morning of ovulation) of the 4-day cycle. On the morning of Day 1 of the next cycle, the oviducts were flushed with saline; the recovered eggs were freed from cumulus cells with hyaluronidase and counted. A fourth group of animals not treated with PMSG (five hamsters per group) served as a control. The hamsters were maintained on a controlled lighting schedule (lights on 05.00 to 19.00 hours, CST) at $23.3^{\circ} \mathrm{C}$ throughout the year. A shipment of hamsters was received on the first Tuesday of each month and only animals with three consecutive 4-day cycles were used. Statistical significance was established by the Duncan's new multiple range test.

The maximal number of ovulations for all groups occurred in the summer and winter months (Table 1). Following the injection of 5 i.u. PMSG, the number of ovulations was not statistically different from that of the untreated controls except for the months of April, May, August and November $(P<0.05$ by Student's $t$ test). The treatment with PMSG apparently did not mature any more follicles than are maintained by endogenous gonadotrophins during the normal oestrous cycle (Greenwald, 1973). On the other hand, 15 i.u. PMSGexcept for October and November-resulted in superovulation presumably by inducing more than the normal number of large preantral follicles to grow. Even more of these so-called 'reserve follicles' were recruited by treatment with 30 i.u. PMSG.

Several possible explanations can be offered to account for the seasonal variation in ovulation rate: (1) environmental changes in the breeding colony 
of origin, (2) or environmental changes during transit to our laboratory; or (3) the persistence of some underlying rhythms in the cycling hamster that modulate ovarian responsiveness to gonadotrophins. Regardless of which explanation is correct, the existence of this seasonal variation should be kept in mind when ovulation is used as an endpoint.

Table 1. Ovulation in normal hamsters and those treated with PMSG

\begin{tabular}{|c|c|c|c|c|}
\hline & Controls & 5 i.u. PMSG & 15 i.u. PMSG & 30 i.u. PMSG \\
\hline $\begin{array}{l}\text { May } \\
\text { June } \\
\text { July } \\
\text { August } \\
\text { September } \\
\text { October } \\
\text { November } \\
\text { December } \\
\text { January } \\
\text { February } \\
\text { March } \\
\text { April }\end{array}$ & $\begin{array}{r}10.2 \pm 0.80(5) \\
* 13.8 \pm 0.66(5) \\
12.0 \pm 0.71(5) \\
10.8 \pm 0.73(5) \\
11.2 \pm 0.73(5) \\
11.4 \pm 0.51(5) \\
9.2 \pm 0.58(5) \\
* 12.8 \pm 0.86(5) \\
* 13.5 \pm 1.04(4) \\
11.4 \pm 0.75(5) \\
11.4 \pm 1.60(5) \\
10.2 \pm 0.58(5)\end{array}$ & $\begin{array}{r}14.0 \pm 0.55(5) \\
* 14.8 \pm 0.58(5) \\
12.6 \pm 0.51(5) \\
13.2 \pm 0.58(5) \\
11.8 \pm 0.73(5) \\
12.0 \pm 1.05(5) \\
12.4 \pm 0.68(5) \\
12.2 \pm 0.58(5) \\
* 15.2 \pm 1.36(5) \\
12.0 \pm 0.71(5) \\
12.0 \pm 0.63(5) \\
13.4 \pm 0.87(5)\end{array}$ & $\begin{array}{r}* 26.0 \pm 1.33(5) \\
* 30.8 \pm 1.56(5) \\
* 26.0 \pm 0.71(5) \\
* 29.4 \pm 1.72(5) \\
* 21.2 \pm 0.86(5) \\
16.2 \pm 1.50(5) \\
14.8 \pm 0.58(5) \\
* 32.4 \pm 2.38(5) \\
* 30.6 \pm 0.98(5) \\
* 27.8 \pm 1.36(5) \\
* 28.4 \pm 1.86(5) \\
* 28.2 \pm 1.63(5)\end{array}$ & $\begin{array}{r}38.4 \pm 2.11(5) \\
* 56.6 \pm 6.56(5) \\
* 47.8 \pm 2.96(5) \\
* 49.2 \pm 1.66(5) \\
42.4 \pm 2.50(5) \\
36.2 \pm 1.66(5) \\
* 57.0 \pm 4.62(5) \\
* 57.0 \pm 4.73(3) \\
* 52.3 \pm 1.55(4) \\
45.2 \pm 2.13(5) \\
33.8 \pm 2.96(5) \\
34.2 \pm 1.27(5)\end{array}$ \\
\hline
\end{tabular}

Values are expressed in terms of the mean number of eggs ovulated \pm S.E., with the number of animals in parentheses.

* Indicates months that differ significantly from others in the same group by Duncan's new multiple range test.

One of us (P.J.M.) was supported as a post-doctoral fellow under training grant 5 TO1 HD 0025 from NICHD and the Ford Foundation. The research was supported by grants from NIH (HD 00596) and the Ford Foundation.

\section{REFERENGE}

Greenwald, G. S. (1973) Effect of an anti-PMS serum on ovulation and oestrogen secretion in the PMS treated hamster. Biol. Reprod. (In press). 